\title{
Faktor Lingkungan Fisik Rumah, Respon Biologis dan Kejadian TBC Paru di Indonesia
}

\author{
A.H. Mahpudin* Renti Mahkota**
}

\begin{abstract}
Abstrak
Sampai kini, Tuberkulosis (TBC) masih menjadi masalah kesehatan masyarakat yang penting di dunia. Menurut laporan WHO, di seluruh dunia setiap tahun ditemukan sekitar 8 juta kasus baru. Indonesia merupakan negara penyumbang kasus TBC terbesar ketiga setelah India dan Cina dengan perkiraan jumlah kasus pada 2003 adalah 627.047 penderita dan 281.946 kasus merupakan TBC paru BTA positif. Tujuan penelitian adalah untuk mengetahui hubungan kondisi lingkungan rumah, faktor sosial ekonomi dan faktor respon biologis terhadap kejadian TBC paru BTA positif pada penduduk dewasa di Indonesia. Penelitian ini menggunakan data sekunder dari Survei Prevalensi TBC Nasional dan Survei Sosial Ekonomi Nasional (Susenas) tahun 2004 dengan rancangan studi kasus kontrol dengan rasio kasus dan kontrol 1:4. Populasi penelitian ini adalah penduduk berumur 15 tahun keatas. Sampel adalah responden Susenas 2004 sebanyak 380 orang yang terdiri dari 76 kasus dan 304 kontrol. Kasus adalah penduduk dewasa yang didiagnosis TBC berdasarkan hasil pemeriksaan sputum BTA positif. Kontrol adalah penduduk yang yang berasal dari kecamatan yang sama dengan kasus dengan hasil BTA negatif. Ditemukan bahwa faktor-faktor yang berhubungan dengan kejadian TBC Paru adalah sumber kontak serumah OR 3,46 $(1,316 ; 9,091)$ kondisi rumah yang berlantai tanah OR 2,2 (1,135;4,269) dan pendapatan perkapita OR 2,145 (1,249;3,683). Disarankan untuk melaksanakan program penemuan kasus secara aktif khusus untuk masyarakat berpenghasilan rendah, terutama untuk deteksi dini, pengobatan secara cepat dan tepat, melaksanakan program penemuan kasus secara aktif, dan program rumah sehat masyarakat miskin.
\end{abstract}

Kata kunci : Lingkungan fisik rumah, sosial ekonomi, respon biologis, tuberkulosis

\begin{abstract}
Globally, Tuberculosis (TB) is an important public health problem until today. Based on WHO report, about 8 millions of new TB cases are found every year. Indonesia is the third biggest contributor country of TB cases after India and China with estimated number of 627.047 infected and 282.946 with positive smear test (BTA) in 2003. The objective of this study is to understand the relationship between house environment condition, socio-economic factor, biological response and TB. This study used secondary source of data from National TB Prevalence Survey (SPTBC) and National Social and Economic Survey (Susenas) in 2004. The study design used is case control study, with ratio of case and control of 1:4. The study population is $\geq 15$ years old age group. The number of sample is 380 persons, consisting of 76 cases and 304 controls. Cases are people with positive sputum test and controls are people with negative sputum test selected randomly. The study results show that factors associated with TB are the presence of contact source in one house with OR 3.46 (1.316-9.091), condition of the house with soil floor OR $2.2(1.135-4.269)$ and private income OR 2.145 (1.249-3.683). According to those findings, it was recommended to the policy maker to conduct active case finding program for the low-income group of people, early detection, quick treatment, active case finding program, and healthy housing for the poor.
\end{abstract}

Key words : House physical environment, social and economic factor, biological response, tuberculosis

*Kepala Seksi Imunisasi Dinas Kesehatan Propinsi Bengkulu, **Staf Pengajar Departemen Epidemiologi Fakultas Kesehatan Masyarakat Universitas Indonesia 
Tuberkulosis (TBC) merupakan penyakit infeksi kronis yang disebabkan oleh bakteri Mycobacterium tuberculosis. Sampai kini, penyakit yang dapat menular secara cepat dan mudah tersebut masih menjadi masalah kesehatan masyarakat yang penting di seluruh dunia. Pada tahun 2003, di seluruh dunia terdapat 8.810.000 kasus baru tuberkulosis dengan 3.897.000 kasus BTA positif. ${ }^{1}$ Tuberkulosis Paru BTA positif tergolong jenis TBC yang sangat menular, karena memproduksi bakteri lebih banyak daripada penderita yang hanya positif pada biakan atau pada pemeriksaan rontgen. Tanpa pengobatan yang memadai, penderita TBC Paru BTA positif tersebut dapat menularkan kepada 10-15 penderita baru setiap tahun. ${ }^{2}$

Penyakit TBC berhubungan sangat erat dengan kemiskinan yang menyebabkan asupan gizi yang kurang, pemukinan yang tidak sehat dan dan akses pelayanan kesehatan yang rendah. Dilain pihak, penyakit TBC yang umumnya menyerang kelompok usia produktif, dapat berdampak langsung dan tidak langsung terhadap ekonomi keluarga. Dampak langsung berupa biaya untuk pengobatan, sedangkan biaya tidak langsung, berupa hilangnya produktifitas kerja, sehingga berdampak pada masalah sosial, keluarga dan masyarakat. ${ }^{3}$

Indonesia menempati peringkat ketiga setelah India dan Cina dari 22 negara yang yang tergolong high burden countries. Jumlah kasus tuberkulosis di Indonesia pada tahun 2003 diperkirakan 627.047 kasus dan 281.946 di antaranya adalah TBC Paru BTA positif. ${ }^{1}$ Berdasarkan Survei prevalensi TBC tahun 2004, prevalensi TBC Paru di Indonesia adalah 119 per 100.000 dan angka insiden 110 per 100.000 penduduk. Dari hasil Survei Kesehatan Rumah Tangga (SKRT), tahun 2001, diketahbui bahwa tuberkulosis berkontribusi sekitar 9,4\% terhadap total kematian. Dengan demikian, tuberkulosis menempati peringkat ketiga penyebab kematian utama setelah penyakit sistem sirkulasi $(26,4 \%)$ dan penyakit sistem pernapasan $(12,7 \%)$. Pada kelompok penyakit infeksi, tuberkulosis berada pada peringkat pertama penyebab kematian, di atas tifus $(4,3 \%)$ dan diare $(3,8 \%) .4$

Sampai kini,angka penemuan kasus TBC di Indonesia masih rendah, pada tahun 2003 dan 2005 angka tersebut baru mencapai $33 \%$ dan $66,8 \%$. Itu berarti bahwa sampai tahun 2005 penemuan kasus belum mencapai target yang telah ditetapkan. Diperkirakan masih banyak kasus TBC paru yang berada di masyarakat yang belum terdeteksi dan mendapat pengobatan. Pengetahuan tentang kelompok risko tinggi TBC Paru di Indonesia, dapat dijadikan acuan dalam menentukan prioritas pencarian kasus TBC secara aktif pada kelompok risiko tinggi tersebut. Dengan demikian, identifikasi faktor-faktor yang berhubungan dengan ke- jadian TBC Paru BTA positif di Indonesia menjadi sangat penting, Berbagai faktor yang berpengaruh terhadap kejadian penyakit TBC Paru, antara lain adalah faktor lingkungan, faktor sosial ekonomi dan faktor respon biologis. Peneliti bertujuan mengetahui hubungan kondisi lingkungan fisik rumah, kondisi sosial ekonomi dan faktor respon biologis dengan kejadian TBC Paru BTA positif pada penduduk dewasa di Indonesia.

\section{Metode}

Penelitian dengan disain studi kasus kontrol ini menggunakan data sekunder hasil Survei Prevalensi Tuberkulosis (SPTBC) dan Susenas tahun 2004. Populasi studi adalah penduduk Indonesia yang berumur 15 tahun keatas yang diperiksa sputumnya pada survei prevalensi TBC Paru 2004. Sampel terdiri dari populasi studi yang berdasarkan pemeriksaan sputum di laboratorium menunjukkan hasil BTA positif dan BTA negatif. Semua penderita yang memenuhi kriteria pemeriksaan mikroskopik sputum sewaktu-pagi-sewaktu (SPS) minimal 1 atau lebih sediaaan BTA positif disertakan. Kriteria ini ditetapkan berdasarkan pertimbangan bahwa kasus dengan hasil pemeriksaan SPS $=1$, tetap berpotensi menularkan TBC Paru kepada orang lain. Sedangkan yang menunjukkan BTA negatif diambil secara random berdasarkan nomor blok sensus atau wilayah kecamatan terdekat dengan kasus sebagai kontrol. Kriteria eksklusi adalah suspek berumur $\geq 15$ tahun yang pernah menderita TBC Paru atau yang sedang menjalani pengobatan pada saat survei dilaksanakan.

Besar sampel ditentukan dengan menggunakan rumus ukuran sampel untuk pengujian hipotesis pada rancangan kasus kontrol. Dengan confident interval 95\% $(\alpha=5 \%)$ dan $\beta=20 \%$, proporsi kontrol yang terpajan faktor risiko $(\mathrm{P} 2)=37 \%$ dan $\mathrm{OR}=2$, besar sampel minimal untuk kasus dan kontrol masing-masing adalah 128. Jumlah penderita TBC paru BTA positif yang ditemukan pada SPTBC 2004 adalah 96 kasus, sehingga jumlah sampel minimal tidak terpenuhi. Untuk mempertahankan power, jumlah sampel ditingkatkan dengan menggunakan rasio kasus dan kontrol ganda $1: 4$. Dengan demikian, subyek pada penelitian ini berjumlah 380 orang, terdiri dari 76 kasus dan 304 kontrol. Analisis data dilakukan dengan menggunakan software SPSS versi 10. Analisis dilakukan secara bertahap meliputi analisis univariat, bivariat dan analisis multivariat.

\section{Hasil}

\section{Seleksi Kandidat Model Multivariate}

Kondisi lingkungan rumah yang diteliti, meliputi variabel pencahayaan kamar tidur, ventilasi kamar tidur, jenis lantai, kepadatan hunian dan keberadaan kontak 
Mahpudin dan Mahkota, Faktor Lingkungan Fisik Rumah, Respon Biologis dan Kejadian TBC Paru

Tabel 1. Hasil Analisis Bivariat Hubungan Antara Lingkungan Rumah dengan Kejadian Tuberkulosis Paru BTA Positif pada Penduduk Dewasa di Indonesia (Analisis data SPTBC dan Susenas 2004)

\begin{tabular}{|c|c|c|c|c|c|c|c|}
\hline \multirow[t]{2}{*}{ Variabel } & \multicolumn{2}{|c|}{ Kasus } & \multicolumn{2}{|c|}{ Kontrol } & \multirow[t]{2}{*}{$P$ value } & \multirow[t]{2}{*}{ Odds Ratio } & \multirow[t]{2}{*}{ 95\% CI } \\
\hline & $\mathbf{n}$ & $\%$ & $\mathbf{n}$ & $\%$ & & & \\
\hline \multicolumn{8}{|c|}{ Pencahayaan kamar } \\
\hline Kurang & 13 & 17,1 & 31 & 10,2 & 0,096 & 1,82 & $0,89-3,67$ \\
\hline Cukup & 63 & 82,9 & 273 & 89,8 & & & \\
\hline \multicolumn{8}{|c|}{ Ventilasi kamar } \\
\hline Kurang & 14 & 18,4 & 40 & 13,2 & 0,242 & 1,49 & $0,76-2,91$ \\
\hline $\begin{array}{l}\text { Cukup } \\
\text { Jenis lantai }\end{array}$ & 62 & 81,6 & 264 & 86,8 & & & \\
\hline Tanah & 19 & 25,0 & 33 & 10,9 & 0,002 & 2,74 & $1,45-5,15$ \\
\hline Bukan tanah & 57 & 75,0 & 271 & 89,1 & & & \\
\hline \multicolumn{8}{|c|}{ Kepadatan hunian } \\
\hline Padat & 22 & 28,9 & 104 & 34,2 & 0,384 & 0,78 & $0,45-1,36$ \\
\hline Tidak padat & 54 & 71,1 & 200 & 65,8 & & & \\
\hline \multicolumn{8}{|c|}{ Kontak Serumah } \\
\hline Ada & 8 & 10,5 & 10 & 3,3 & 0,012 & 3,46 & $1,32-9,09$ \\
\hline Tidak ada & 68 & 89,5 & 294 & 96,7 & & & \\
\hline
\end{tabular}

Tabel 2. Hasil Analisis Bivariat Hubungan Antara Faktor Sosial Ekonomi dengan Kejadian Tuberkulosis Paru BTA Positif pada Penduduk Dewasa di Indonesia (Analisis data SPTBC dan Susenas 2004)

\begin{tabular}{|c|c|c|c|c|c|c|c|}
\hline \multirow[t]{2}{*}{ Variabel } & \multicolumn{2}{|c|}{ Kasus } & \multicolumn{2}{|c|}{ Kontrol } & \multirow[t]{2}{*}{ P value } & \multirow[t]{2}{*}{ Odds Ratio } & \multirow[t]{2}{*}{$95 \% \mathbf{C I}$} \\
\hline & $\mathbf{n}$ & $\%$ & $\mathbf{n}$ & $\%$ & & & \\
\hline \multicolumn{8}{|c|}{ Tingkat pendidikan } \\
\hline Rendah & 63 & 82,9 & 258 & 84,9 & - & 1,00 & - \\
\hline Menengah & 11 & 14,5 & 32 & 10,5 & 0.487 & 0,59 & $0,13-2,64$ \\
\hline Tinggi & 2 & 2,6 & 14 & 4,6 & 0,292 & 0,42 & $0,08-2,13$ \\
\hline \multicolumn{8}{|l|}{ Pekerjaan } \\
\hline Tidak bekerja & 25 & 32,9 & 105 & 34,5 & 0,787 & 0,93 & $0,55-1,58$ \\
\hline Bekerja & 51 & 67,1 & 199 & 65,5 & & & \\
\hline \multicolumn{8}{|c|}{ Status perkawinan } \\
\hline Tidak kawin & 10 & 13,2 & 65 & 21,4 & 0,111 & 1,79 & $0,87-3,68$ \\
\hline Kawin & 66 & 86,8 & 239 & 78,6 & & & \\
\hline \multicolumn{8}{|c|}{ Pendapatan perkapita } \\
\hline Rendah & 28 & 36,8 & 65 & 21,4 & 0,006 & 2,15 & $1,25-3,68$ \\
\hline Tinggi & 48 & 63,2 & 239 & 78,6 & & & \\
\hline
\end{tabular}

serumah. Terlihat bahwa variabel pencahayaan, ventilasi, jenis lantai dan kontak serumah memenuhi kriteria kandidat model multivariat (nilai $\mathrm{p} \leq 0,025$ ). (Lihat Tabel 1)

Kondisi lingkungan sosial ekonomi yang diteliti meliputi variabel tingkat pendidikan, pekerjaan, status perkawinan dan pendapatan perkapita. Variabel yang memenuhi kreteria kandidat model adalah status perkawinan dan pendapatan perkapita. (Lihat Tabel 2)

Karakteristik biologis yang memenuhi kriteria variabel kandidat model multivariat adalah jenis kelamin dengan nilai $\mathrm{p}=0,198$. (Lihat Tabel 3)

Pemilihan variabel kandidat model yang masuk analisis multivariat dilakukan berdasarkan kriteria dari Lemeshow, ${ }^{5}$ yaitu variabel yang pada analisis bivariat menunjukkan $p$ value $<0,25$ atau variabel tersebut secara substansi dianggap penting. Hasil analisis tersebut sebagai-mana terlihat pada tabel 4 .
Dari hasil analisis pada tabel 4 didapatkan kandidat variabel yang akan dimasukkan ke dalam model yaitu variabel pencahayaan kamar, jenis lantai, keberadaan sumber kontak serumah, status perkawinan, pendapatan perkapita dan jenis kelamin. Variabel lain seperti ventilasi kamar, kepadatan hunian, tingkat pendidikan, status pekerjaan dan umur tidak dimasukkan kedalam model karena $\mathrm{p}$ value $>0,25$.

Setelah kandidat variabel model diperoleh, selanjutnya dilakukan pemilihan model terbaik. Analisis dilakukan dengan metode regresi logistik ganda menggunakan teknik backward stepwise selection, yaitu dengan cara memasukkan secara bersamaan (sekaligus) variabel hasil analisis bivariat yang memiliki nilai $\mathrm{p}<$ 0,25 dan memiliki kemaknaan biologis ke dalam model regresi. Kemudian dilakukan seleksi dengan mengeluarkan variabel penelitian satu persatu dari model.Variabel yang pertama dikeluarkan dari model 
Tabel 3. Hasil Analisis Bivariat Hubungan Respon Biologis dengan Kejadian Tuberkulosis Paru BTA Positif Pada Penduduk Dewasa di Indonesia (Analisis data SPTBC dan Susenas 2004)

\begin{tabular}{|c|c|c|c|c|c|c|c|}
\hline \multirow[t]{2}{*}{ Variabel } & \multicolumn{2}{|c|}{ Kasus } & \multicolumn{2}{|c|}{ Kontrol } & \multirow[t]{2}{*}{ P value } & \multirow[t]{2}{*}{ Odds Ratio } & \multirow[t]{2}{*}{ 95\% CI } \\
\hline & $\mathbf{n}$ & $\%$ & $\mathbf{n}$ & $\%$ & & & \\
\hline \multicolumn{8}{|l|}{ Umur } \\
\hline 50 tahun keatas & 28 & 36,8 & 114 & 37,5 & 0,916 & 0,972 & $0,58-1,64$ \\
\hline $\begin{array}{l}15-49 \text { tahun } \\
\text { Jenis kelamin }\end{array}$ & 48 & 63,2 & 190 & 62,5 & & & \\
\hline Laki- laki & 47 & 61,6 & 163 & 53,6 & 0,198 & 1,402 & $0,84-2,35$ \\
\hline Perempuan & 29 & 38,2 & 141 & 46,4 & & & \\
\hline
\end{tabular}

Tabel 4. Hasil Analisis Regresi Logistik Bivariat Faktor-faktor yang Berhubungan dengan Kejadian Tuberkulosis Paru BTA Positif Pada Penduduk Dewasa di Indonesia (Analisis Data SPTBC dan Susenas 2004)

\begin{tabular}{llll}
\hline Variabel & P value & OR & OR 95\% CI \\
\hline Pencahayaan kamar * & 0,107 & 1,817 & 0,$899 ; 3,671$ \\
Ventilasi kamar & 0,253 & 1,490 & 0,$764 ; 2,906$ \\
Jenis lantai * & 0,003 & 2,737 & 1,$454 ; 5,152$ \\
Kepadatan hunian & 0,379 & 0,784 & 0,$452 ; 1,357$ \\
Kontak serumah * & 0,016 & 3,459 & 1,$316 ; 9,091$ \\
Tingkat pendidikan & & & \\
rendah & - & 1 & Reference \\
menengah & 0,487 & 0,586 & 0,$130 ; 2,642$ \\
tinggi & 0,292 & 0,416 & 0,$081 ; 2,127$ \\
Pekerjaan & 0,786 & 0,929 & 0,$545 ; 1,584$ \\
Status perkawinan * & 0,094 & 1,793 & 0,$874 ; 3,681$ \\
Pendapatan perkapita * & 0,007 & 2,145 & 1,$249 ; 3,683$ \\
Umur & 0,915 & 0,972 & 0,$678 ; 1,636$ \\
Jenis kelamin * & 0,195 & 1,402 & 0,$838 ; 2,346$ \\
& & & \\
\hline
\end{tabular}

*) masuk kandidat model, $\mathrm{p}<0,25$

adalah variabel yang mempunyai korelasi parsial terkecil dengan variabel independen. Default standar SPSS untuk mengeluarkan suatu variabel dari model adalah 0,1 , artinya variabel yang mempunyai $P$ value $\geq 0,10$ dikeluarkan dari model. Proses pengeluaran variabel dari model terus dilakukan sampai tidak ada lagi variabel di dalam model yang dapat dikeluarkan oleh kriteria tersebut sehingga diperoleh model dengan masing-masing variabel mempunyai nilai kemaknaan secara statistik.

Penilaian interaksi dilakukan untuk mengetahui adanya interaksi atau efek modifikasi diantara faktor risiko. Bila diketahui terjadi interaksi, maka variabel interaksi ini perlu dimasukkan kedalam model. Namun setelah dilakukan uji interaksi ternyata diketahui tidak terdapat bukti secara statistik adanya interaksi diantara faktor risiko pada penelitian ini. Dengan demikian model akhir dari faktor risiko yang berhubungan dengan kejadian TBC paru BTA positif adalah sebagaimana yang terlihat pada Tabel 5 .

Berdasarkan Tabel 5, diperoleh model yang cocok pada penelitian ini adalah model yang terdiri dari faktor risiko jenis lantai, keberadaan kontak serumah dan pendapatan perkapita, tanpa adanya variabel interaksi. Dengan demikian model tersebut telah menjadi model fit yang hasilnya telah dikontrol oleh variabel lain.
Dari keseluruhan proses analisis yang telah dilakukan dapat disimpulkan bahwa dari 11 variabel independen yang diduga berhubungan dengan kejadian TBC Paru BTA positif, ternyata hanya tiga yang secara signifikan berhubungan, yaitu jenis lantai, keberadaan kontak dan pendapatan perkapita. Mereka yang tinggal di rumah berlantai tanah mempunyai risiko untuk menderita tuberkulosis paru 2,2 kali (95\% CI $1,135 ; 4,269)$, dibandingkan dengan mereka yang tinggal dirumah yang berlantai bukan tanah setelah dikontrol variabel keberadaan kontak dan pendapatan perkapita. Mereka yang tinggal serumah dengan kontak (mempunyai anggota keluarga yang menderita tuberkolosis paru) mempunyai risiko untuk menderita tuberkulosis paru 3,16 kali $(95 \%$ CI 1,$167 ; 8,554)$, dibandingkan dengan mereka yang tidak mempunyai kontak serumah setelah dikontrol variabel jenis lantai dan pendapatan perkapita. Mereka yang mempunyai pendapatan perkapita rendah (dibawah garis kemiskinan) mempunyai risiko untuk menderita tuberkulosis paru 1,87 kali (95\% CI 1,060;3,285), dibandingkan dengan mereka yang mempunyai pendapatan perkapita tinggi (diatas garis kemiskinan) setelah dikontrol variabel jenis lantai dan keberadaan kontak.

Selanjutnya dapat disimpulkan bahwa dari ketiga variabel tersebut, variabel keberadaan kontak serumah merupakan variabel yang paling dominan berhubungan dengan kejadian TBC paru BTA positif pada penduduk Indonesia yang berumur 15 tahun keatas.

\section{Pembahasan}

Setiap penelitian tidak terlepas dari kemungkinan adanya keterbatasan yang dapat mempengaruhi kualitas hasil penelitian, namun hal ini dapat diperkecil pengaruhnya dengan cara mengoptimalkan kualitas data, ketepatan dalam memilih desain studi dan menjaga kualitas analisis. Berikut akan diuraikan mengenai hal-hal yang berkaitan dengan keterbatasan penelitian dan upaya untuk meningkatkan kualitas penelitian.

\section{Kualitas Data}

Penelitian ini menggunakan data sekunder yang ber- 
Mahpudin dan Mahkota, Faktor Lingkungan Fisik Rumah, Respon Biologis dan Kejadian TBC Paru

Tabel 5. Model Akhir Regresi Logistik Multivariat

\begin{tabular}{llllll}
\hline Faktor risiko & Koefisien & S.E & P value & Odds Ratio & OR pada 95\% CI \\
\hline Jenis Lantai & 0,789 & 0,338 & 0,020 & 2,201 & 1,$135 ; 4,269$ \\
Keberadaan kontak & 1,150 & 0,508 & 0,024 & 3,160 & 1,$167 ; 8,554$ \\
Pendapatan perkapita & 0,624 & 0,288 & 0,031 & 1,866 & 1,$060 ; 3,285$ \\
Konstanta & $-0,792$ & 0,565 & 0,161 & - & \\
& & & &
\end{tabular}

asal dari Susenas 2004 dan Survey Prevalensi TB Nasional 2004. Tujuan pengumpulan data tersebut berbeda dengan tujuan penelitian ini, sehingga peneliti tidak punya kontrol terhadap jumlah, jenis variabel yang dikumpulkan serta kualitas data. Upaya untuk mengoptimalkan kualitas data yang dilakukan antara lain adalah penanganan missing data dan penetapan cut of point dari beberapa variabel berskala rasio. Variabel pendidikan yang mengalami missing data ternyata secara konsisten terdapat pada kelompok yang tidak mempunyai kemampuan membaca huruf latin (buta huruf). Berdasarkan hal tersebut, dilakukan pengkodean ulang pada setiap variabel pendidikan dengan missing data diberikan kode 0 . Hal yang sama ditemukan pada pada variabel pencahayaan kamar dan ventilasi kamar karena jumlah ruangan dalam rumah hanya satu, sehingga berfungsi sebagai ruang serbaguna termasuk untuk tempat tidur. Pengkodean variabel pencahayaan kamar dan ventilasi kamar ditentukan berdasarkan status pencahayaan dan ventilasi pada ruang serbaguna tersebut.

\section{Bias dalam Penelitian}

Pada desain studi kasus kontrol, bias yang sering terjadi adalah bias seleksi yang disebabkan oleh adanya kontrol berasal dari populasi yang berbeda dengan kasus. Pada penelitian ini, bias seleksi kemungkinan besar tidak terjadi karena kontrol dipilih dari populasi tempat kasus berasal. Jenis bias lain yang mungkin terjadi pada penelitian ini adalah bias informasi. Bias informasi adalah bias yang disebabkan oleh cara mengamati, mengukur, mencatat, mengklasifikasi dan menginterpretasi status pajanan atau penyakit. Pada penelitian ini bias informasi yang mungkin terjadi antara lain adalah bias yang diakibatkan oleh instrumen, recall bias dan bias dari pewawancara (interviewer bias). Bias tersebut dapat terjadi pada pengukuran ventilasi dan pencahayaan yang tidak dilakukan secara objektif. Ventilasi rumah diukur dengan kriteria keberadaan lubang ventilasi, sedangkan pencahayaan berdasarkan daya penglihatan pewawancara untuk membaca dengan jelas pada ruangan yang diukur. Recall bias mungkin terjadi karena pada kuesioner yang menuntut ingatan responden, seperti pertanyaan jumlah pengeluaran rumah tangga sebulan yang lalu dan pertanyaan mengenai riwayat keberadaan kontak serumah.

\section{Faktor Lingkungan Rumah}

Variabel lingkungan rumah yang berhubungan dengan kejadian tuberkulosis paru BTA positif adalah jenis lantai dan keberadaan kontak serumah Mereka yang bertempat tinggal di rumah berlantai tanah $\mathrm{OR}=2,2$ 95\% CI 1,1 - 4,2).

Jenis lantai tanah dapat mencerminkan kondisi rumah yang sangat sederhana, yang tidak memenuhi persyaratan, sulit dibersihkan, berdebu, cenderung lembab dan gelap. Hal tersebut merupakan kondisi ideal bagi berbagai jenis bakteri dan virus untuk bertahan hidup lebih lama. Penderita TBC paru BTA positif yang masuk ke dalam rumah tersebut relatif lebih mudah menular pada penghuni yang lain. ${ }^{2}$ Beberapa penelitian menemukan hubungan yang bermakna antara kondisi rumah dengan kejadian TBC paru. Penelitian di Garut Jawa Barat menemukan bahwa mereka yang tinggal di rumah yang tidak memenuhi syarat mempunyai risiko 5,61 kali $(95 \%$ CI 2,43;12,0) lebih besar untuk tertular TBC daripada mereka yang tinggal di rumah dengan kondisi yang baik. ${ }^{6}$

Sumber kontak serumah terlihat berhubungan secara bermakna dengan kejadian tuberkulosis paru BTA positif. Mereka yang tinggal serumah dengan kontak berisiko menderita tuberkulosis paru 3,16 kali (95\% CI $1,167 ; 8,554)$, daripada mereka yang tidak ada kontak serumah. Temuan ini sesuai penelitian sebelumnya, penelitian di Palembang kontak serumah berisiko 41,8 kali $(95 \%$ CI 15,23;114,90) daripada yang tanpa kontak serumah. ${ }^{7}$ Penelitian di Kabupaten Majalengka 8,59 kali $(95 \%$ CI 3,23;22,85). 8 Di provinsi Sulawesi Tengah $\left(\mathrm{OR}=4 ; 95 \%\right.$ CI 2,7 - 5,8). ${ }^{9}$ Kontak serumah merupakan ancaman yang sangat serius bagi anggota keluarga lainnya untuk menderita penyakit tuberkulosis, karena merupakan sumber penularan intensif yang berada di sekitar kehidupan sehari-hari anggota keluarga lainnya. Kontak erat dengan penderita TBC paru BTA positif berisiko maksimum untuk terjadinya infeksi. Keterlambatan dalam memberikan pengobatan akan memperbesar kemungkinan terjadinya risiko penularan. ${ }^{9}$ 


\section{Faktor Lingkungan Sosial Ekonomi}

Pada faktor lingkungan sosial ekonomi yang secara statistik berhubungan bermakna dengan kejadian tuberkulosis paru BTA positif hanya pendapatan perkapita. Dari analisis multivariat, terlihat bahwa subjek penelitian dengan pendapatan perkapita yang rendah berisiko menderita tuberkulosis paru 1,9 kali (95\% CI $1,060 ; 3,285)$, daripada mereka yang dengan pendapatan perkapita tinggi. Temuan ini berbeda dengan hasil penelitian sebelumnya. Penelitian di Jakarta Timur, dan Jambi menemukan hasil yang tidak berhubungan bermakna bermakna dengan kejadian TBC paru BTA positif. ${ }^{10,11}$ Perbedaan tersebut diduga akibat perbedaan cara mengukur dan menentukan cut of point. Pada penelitian ini, pendapatan perkapita diukur berdasarkan jumlah pengeluaran rata-rata perbulan per jumlah anggota keluarga, sedangkan cut of poin ditentukan berdasarkan kriteria BPS yang menetapkan batas miskin (proverty line) sebesar Rp143.455 untuk daerah perkotaan dan Rp108.725 untuk daerah pedesaan. Pada penelitian Budiyono, ${ }^{10}$ cut of point dilakukan berdasarkan nilai mean sedangkan pada penelitian Silviana, ${ }^{11}$ menggunakan kriteria pendapatan rata-rata dibawah Rp700.000 perbulan untuk kelompok pendapatan rendah dan diatas Rp700.000 perbulan untuk kelompok berpendapatan tinggi.

Pendapatan perkapita menggambarkan kemampuan ekonomi seseorang yang secara luas berpengaruh terhadap aspek-aspek kehidupan lainnya, seperti perilaku sehat, pendidikan, perumahan dan lainnya. Dari aspek kesehatan, keluarga dengan pendapatan perkapita yang tinggi dapat memenuhi kebutuhan anggota keluarganya, seperti kebutuhan gizi, tempat tinggal yang sehat dan pemeliharaan kesehatan, sehingga dapat menurunkan risiko terjadinya penyakit TBC. Hubungan antara pendapatan perkapita dengan tuberkulosis, dapat terjadi secara timbal balik. Dalam kondisi tertentu, TBC paru yang menyerang anggota keluarga yang menjadi tulang punggung ekonomi keluarga dapat secara langsung mempengaruhi pendapatan perkapita keluarga, akibat hilangnya hari kerja produktif. ${ }^{3}$

\section{Faktor Respon Biologik}

Variabel respon biologik yang diteliti pada penelitian ini hanya terdiri dari variabel umur dan variabel jenis kelamin. Berdasarkan analisis bivariat tidak ada satupun dari variabel tersebut yang berhubungan secara bermakna dengan kejadian tuberkulosis. Hal tersebut kemungkinan disebabkan oleh variabel tersebut tersebar secara homogen pada kelompok kasus dan kontrol. Pada variabel umur, kelompok yang berumur 50 tahun keatas mempunyai proporsi sebesar $36,8 \%$ pada kasus dan $37,4 \%$ pada kontrol. Pada kelompok umur 49 tahun ke- bawah mempunyai proporsi sebesar $63,2 \%$ pada kasus dan $62,5 \%$ pada kontrol. Pada variabel jenis kelamin, jenis kelamin laki-laki pada kasus adalah $61,8 \%$ dan pada kontrol adalah 53,6\%, sedangkan jenis kelamin perempuan $38,2 \%$ pada kasus dan $46,4 \%$ pada kontrol.

\section{Kesimpulan}

Dari hasil penelitian ini dapat diambil beberapa kesimpulan sebagai berikut:

1. Berdasarkan kondisi lingkungan rumah, variabel yang berhubungan dengan TBC Paru BTA positif adalah jenis lantai dan kontak serumah. Sedangkan faktor sosial ekonomi, yang berhubungan dengan TBC Paru BTA positif adalah pendapatan perkapita.

2. Mereka yang mempunyai pendapatan perkapita rendah berisiko untuk menderita TBC paru berisiko lebih besar untuk menderita TBC paru = paru daripada mereka yang mempunyai pendapatan perkapita tinggi.

3. Dari ketiga variabel tersebut, variabel keberadaan sumber kontak serumah merupakan variabel yang paling dominan berhubungan dengan kejadian TBC paru BTA positif pada penduduk Indonesia yang berumur 15 tahun keatas.

\section{Saran}

1. Program pemberantasan TBC paru di Indonesia perlu memprioritaskan upaya penemuan penderita sedini mungkin khususnya pada kelompok sosial ekonomi rendah dan memberikan pengobatan secara cepat untuk memutus rantai penularan.

2. Perlu dipertimbangkan kembali untuk melaksanakan program penemuan kasus secara aktif (active case finding) khususnya pada kelompok sosial ekonomi rendah.

3. Untuk jangka panjang, perlu kerjasama lintas sektor untuk melaksana-kan program rumah sehat, khususnya perbaikan rumah penduduk yang berlantai tanah.

4. Untuk peneliti perlu dilakukan penelitian tentang tuberkulosis paru dengan menggunakan data SPTBC, SKRT dan Susenas 2004 yang terintegrasi.

\section{Daftar Pustaka}

1. WHO. Global tuberculosis control, surveillance, planning, financing. WHO: Geneva; 2005

2. Crofton, John. Tuberkulosis klinis, edisi bahasa Indonesia, Muherman Harun, edisi 2, Widya Medika: Jakarta; 2002

3. Aditama, Tjandra Y. Tuberkulosis dan kemiskinan, Majalah Kedokteran Indonesia, 55 (2), 49-50; 2005

4. Tim Surkesnas. Laporan studi mortalitas 2001, Pola penyakit penyebab kematian di Indonesia. Badan Penelitian dan Pengembangan Kesehatan Depkes RI: Jakarta; 2002

5. Lemeshow, Stanley. Besar sampel dalam penelitian kesehatan, Edisi 
Bahasa Indonesia. Gajah Mada University Press: Yogyakarta; 1997

6. Supariasa, I Dewa Nyoman. Penilaian status gizi. Penerbit Buku Kedokteran EGC: Jakarta; 2001

7. Versitaria. HU. Hubungan sumber penular dan lingkungan di dalam rumah terhadap kejadian TBC Paru BTA (+) di Kota Palembang Tahun 2003, [Tesis] Program Pascasarjana FKM UI: Depok; 2003

8. Rochendy, Iid. Hubungan lingkungan fisik rumah dengan status penderita tuberkulosis paru BTA Positif di Kabupaten Majalengka tahun 2000, [Tesis] Program Pascasarjana FKM UI: Depok; 2001
9. Apriani, Wayan. Faktor-faktor yang berhubungan dengan kejadian TB paru di Kabupaten Donggala Provinsi Sulawesi Tengah Tahun 2000. [Tesis] Program Pascasarjana FKM UI: Depok; 2001

10. Budiyono, FX. Faktor-faktor yang berhubungan dengan kejadian tuberkulosis paru BTA positif di Kota Jakarta Timur Tahun 2003. [Tesis] Program Pascasarjana FKM UI: Depok; 2003

11 Silviana, Ike. Hubungan lingkungan fisisk dalam rumah terhadap kejadian tuberkulosis paru BTA (+) di Kabupaten Muara Jambi Tahun 2005. [Tesis] Program Pascasarjana FKM UI: DEpok; 2005 